\title{
Entrevista com Horst Gundlach
}

Interview with Horst Gundlach

\author{
Monalisa Maria Lauro \\ Cíntia Fernandes Marcellos ${ }^{\mathrm{II}}$
}

IPrograma de Pós-Graduação em Psicologia, Universidade Federal de Juiz de Fora

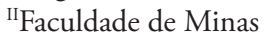

Considerado um dos mais respeitados e importantes pesquisadores em Historiografia da Psicologia, o professor doutor Horst Gundlach estudou Psicologia e Filosofia nas universidades alemãs de Heidelberg e München. Suas contribuiçôes incluem numerosos artigos e livros e a direção de dois importantes centros de pesquisas historiográficas na Alemanha, o Instituto de História da Psicologia (Institut für Geschichte Psychologie), da Universidade de Passau, e o Centro Adolf Würth de História da Psicologia (AdolfWürth-Zentrum für Geschichte der Psychologie), da Universidade de Würzburg. Além disso, ele também participou na criação da Sociedade Europeia para História das Ciências Humanas, desenvolveu pesquisas no Instituto Max Planck e lecionou nas Universidades de Passau e de Wüzburg. Após se aposentar, em 2010, Gundlach mudou-se para Heidelberg, onde tem continuado seus estudos.

Entre 27 e 29 de agosto de 2012, o professor esteve no Brasil para participar do Primeiro Congresso Internacional de Psicologia, do Quinto Congresso de Psicologia da Zona da Mata e Vertentes e do Nono Encontro Juiz-forano de Psicologia. Naquela ocasião, conduziu um workshop sobre questóes metodológicas centrais na pesquisa em história da psicologia e o surgimento da Psicologia Aplicada no século 20, concedendo-nos a presente entrevista.

1. Psicologia em Pesquisa: You have been working in the history of psychology field for more than three decades. How do you evaluate its importance for Psychology development as well as for its current situation?

Gundlach: My personal conviction is that psychologists of whatever specialties could learn much from the history of psychology, concerning their special field of research, psychology in general as well as the role that it could/should or could not/ should not play in the society and in cooperation with neighboring sciences. An important lesson would be to realize how important it is for Psychology in general as for any other science to develop a precise and coherent terminology.

2. Psicologia em Pesquisa: How do you see the debates and transformations that happened in the Historiography of the Science in the last 30 years?

Gundlach: These debates have opened new fields of research for historians of psychology, new methods, and - I do hope - a greater acceptance of a plurality of approaches. An important development is that more and more general historians of science direct their attention to the history of psychology; however, sometimes, they do it without adequate knowledge of the science of psychology. Here, psychologists doing research in this field will have to play a more prominent role.

3. Psicologia em Pesquisa: In your opinion, what was the main contribution of the Institute for the History of Psychology at Passau University in order to develop such field in Europe, especially in Germany?

Gundlach: In all modesty, the more permanent contributions were materials' collection and preservation of this field, such as the states of a number of psychologists, instruments of research laboratories as well as of applied psychology, tests, films, photographs, etc., plus the successful removal of this material to the University of Würzburg. Other contributions consist in the congresses and in the publications.

4. Psicologia em Pesquisa: In some of your papers, e.g. Psychology as Science and as Discipline: the Case of Germany (2006), the distinction between two senses of the term 'Psychology' as a science and as a discipline - is essential for understanding its history. According to your view, 
what is the implication of this distinction for the historiography of Psychology? Which limitations do you notice for using these categories? Could they merge, for example, when we consider the different conceptions of science that followed in the history of Psychology?

Gundlach: Historiographers of Psychology should keep in mind this distinction whenever they try to come to abstract conclusions about Psychology. The distinction is, of course, not very useful when there was no discipline of Psychology — but then, some historians do not realize that there was in times of no discipline nonetheless a science of Psychology. Take, for example, Helmholtz. At his demise centenary, many historians had congresses with topics like Helmholtz and physics, Helmholtz and physiology, Helmholtz and neurology, Helmholtz and perception, and so on. Nobody talked about him and psychology, because he was not a psychologist - a rather simple-minded argument. But, he certainly made many important discoveries that belong to the science of Psychology, in times when the disciplinary status of psychology was next to nonexistent.

5. Psicologia em Pesquisa: Still considering the distinction between science and discipline, how do you see their reciprocal influence? How should we conceive the influence of Psychology as a discipline on its development as a science, as well as their relation to its professionalization?

Gundlach: A very complicated issue - a prominent influence concerns the boundaries. A discipline may tend to draw boundaries for its subject, which may not coincide with those of science. Look at all the work done on topics of psychology inside the disciplines of biology, physiology, neurology, psychiatry, etc. All these things may appear as not belonging to psychology, because they were done by people or institutions that are not specialists in the discipline of psychology.

6. Psicologia em Pesquisa: Psychological instruments are one of the subjects of your interest. You have proposed a History of Psychology (as science and as discipline) based on the History of Psychological Instruments. Since the definition of a psychological instrument has not only a conceptual aspect, but also a contextual one, can we say that in this kind of history we would find some equilibrium between externalist and internalist perspectives of the historiography of psychology?

Gundlach: As a large number of psychological instruments were conceivable and realizable only after discoveries in physics and related sciences, and inventions and developments in technology were made, the use of instruments in psychology is certainly an area in which the intertwining of external and internal factors is very prominent. Another matter is, of course, psychological research financing. Since most instruments are or were expensive, their use (as well as the nonuse of very expensive instruments available in the market) is another aspect where both factors are of interest.

7. Psicologia em Pesquisa: Psychology and philosophy are interrelated fields of knowledge regarding the nature of their subject matter. However, the training of new psychologists in Brazil seems to be increasingly distant from a philosophical reflection. We would like to know how you see this relationship and its situation in your country.

Gundlach: As Wundt and other people stated: 'any science is interrelated with philosophy, and psychology probably as much as physics or cosmology.' The conceptual problem is the following: authors like Descartes, Locke, Leibniz, Wolff, Aristotle and Plato are classified as philosophers. Therefore, some psychologists assume that they are of only marginal interest for psychology. However, in their days the concept of philosophy was much broader than it is nowadays. Only some of their ideas belonged to the present discipline of philosophy, others belonged to psychology, etc.

One of the issues of the present relation between adherents of psychology and those of philosophy seems to be that in the latter there is still some kind of nonempirical psychology in the making (philosophy of mind or similar fields), which consist of reflections on folk psychology (everyday psychology, coffeehouse psychology, whatever you want to call it). This fact to psychologists looks as being far below present scientific standards of psychological research — and also afraid of expressing quantities in numbers - , therefore a waste of time. While, on the other hand, philosophers 
underestimate the effort it takes to understand what psychologists are doing nowadays. Therefore, if there are discussions between these two fields, they usually result in frustration on both sides - at least in Germany where I have witnessed them.

8. Psicologia em Pesquisa: Finally, how do you evaluate the relationship between philosophy of psychology and history of psychology?

Gundlach: If you mean basic questions of philosophy that concern matters of psychology, there can be a very valuable exchange between these fields. However, they are independent of each other. 